\title{
TINDAK TUTUR MEMUJI BAHASA JEPANG DI KALANGAN WANITA JEPANG
}

\author{
Rita Susanti ${ }^{1}$, Maduma Siregar ${ }^{2}$ \\ ${ }^{1}$ Jurusan Bahasa dan Sastra Jepang, Fakultas Sastra, Universitas Nasional, \\ Jl.Sawo Manila, Pejaten, Pasar Minggu, Jakarta \\ ${ }^{2}$ English Department, Faculty of Language and Culture, Bina Nusantara University, \\ Jln. Kemanggisan Ilir III No. 45, Kemanggisan/Palmerah, Jakarta Barat 11480, \\ uniritas@yahoo.co.jp
}

\begin{abstract}
The aim of this research is to discover the type, form, and function of Japanese woman in using compliments. Data is taken from the manga Cardcaptor Sakura volume 3 to 5, written by CLAMP manga writer group. Analysis found several types of compliment found in and the form of compliment used are adjectives. The reason Japanese woman give compliment to others is to express an admiration of something positive that belongs to the listener.
\end{abstract}

Keywords: speech act, compliment, Japanese woman

\begin{abstract}
ABSTRAK
Artikel bertujuan untuk mengetahui jenis, bentuk, dan alasan wanita Jepang melakukan pujian terhadap petutur. Data diambil dari komik yang berjudul Cardcaptor Sakura jilid 3-5 karya grup komikus CLAMP. Berdasarkan hasil analisis ditemukan semua jenis tindak tutur memuji di kalangan wanita Jepang dan bentuk tindak tutur memuji yang digunakan merupakan adjektiva. Alasan wanita Jepang melakukan tindak tutur memuji adalah untuk penilaian positif terhadap sesuatu yang dimiliki orang lain.
\end{abstract}

Kata kunci: tindak tutur, memuji, wanita Jepang 


\section{PENDAHULUAN}

Pragmatik saat ini sudah menjadi bagian dari kajian linguistik, meskipun pada awalnya masih dianggap sebelah mata. Bahkan ada ungkapan bahwa pragmatik merupakan keranjang sampai dari cabang ilmu linguistik lainnya. Pragmatik itu sendiri adalah ilmu yang mempelajari maksud ujaran yang dikaitkan dengan pengguna bahasa dan konteks. Sejak Austin mengemukakan teori tindak tutur, pragmatik mulai diakui keberadaannya. Tindak tutur menurut Austin (dalam Nadar, 2009:11) bahwa pada dasarnya saat seseorang mengujarkan kalimat tertentu dapat dilihat sebagai melakukan tindakan (act), di samping memang mengujarkan kalimat tersebut.

Pada saat seseorang mengujarkan atau bertutur "cantik sekali bajumu", tentunya tidak sekedar mengucapkan kata-kata itu, tetapi ada maksud tertentu dari orang yang menuturkan (penutur), yaitu ia ingin memuji busana yang sedang dipakai oleh lawan bicara (petutur). Pujian merupakan salah satu kajian di dalam pragmatik. Menurut Searle (dalam Leech, 1983: 164-166) pujian termasuk ke dalam makro fungsi ekspresif, yaitu menyatakan sesuatu dari dalam hati.

Memuji berasal dari kata puji, yaitu rasa pengakuan dan penghargaan yang tulus akan kebaikan (keunggulan) sesuatu. Dalam hal memuji, tentunya tidak hanya pilihan kata yang menjadi perhatian, tetapi harus memperhatikan muka (face) petutur. Muka adalah citra diri atau wujud pribadi seseorang dalam masyarakat. Dengan memperhatikan muka petutur, selain menentukan bentuk pilihan pujian juga akan menentukan strategi yang akan dipilih oleh penutur. Tujuan penutur mengujarkan pujian agar pujian itu menjadi suatu yang baik bagi petutur.

Memuji dilakukan baik oleh pria maupun wanita dan hal yang dipuji tidak hanya pada satu hal saja. Penelitian terfokus pada tindak tutur memuji yang digunakan oleh wanita Jepang, hal apa yang dipuji, dan bagaimana bentuk pujian tersebut. Data diperoleh dari komik Cardcaptor Sakura jilid 3-5 karaya Ageha Ohkawa, Makoma, et all

\section{PEMBAHASAN}

\section{Tindak Tutur Memuji}

Memuji adalah tindak tutur yang secara langsung atau tidak langsung memberikan penghargaan kepada seseorang selain penutur, biasanya petutur atas beberapa "kelebihan yang dimilikinya, seperti kepunyaan keahlian, dan lain-lain.tindak tutur yang secara langsung atau tidak langsung memberikan penghargaan kepada seseorang. Jadi, tindak tutur memuji adalah tindakan melakukan pujian yang dilakukan seseorang (penutur) terhadap orang lain (petutur). Brown dan Levinson (dalam Holmes, 2003:177) memaparkan bahwa pujian adalah contoh utama tindak tutur yang memperhatikan dan mengikuti minat (interest), keinginan (wants), kebutuhan (needs), dan penampilan (goods) petutur. Brown dan Levinson juga menyatakan bahwa pujian merupakan strategi kesantunan positif.

Austin (dalam Nadar, 2009:11) menyebutkan bahwa pada dasarnya saat seseorang mengujarkan kalimat tertentu dapat dilihat sebagai melakukan tindakan (act), di samping memang mengucapkan (mengujarkan) kalimat tersebut. Pernyataan Austin tersebut meletakkan dasar pengertian tindak tutur yang secara jelas dapat dilihat dari contoh kalimat berikut ini.

(1) 今週中に履歴書を出してください。

(Nihongo Bunkei Jiten, 1998:249)

'Tolong kirimkan CV anda dalam minggu ini.' 
Contoh (1) menampilkan makna semantik, sedangkan kalau dilihat dari sudut pandang pragmatik ujaran tersebut bukan sebatas mengujarkan, tetapi penutur meminta kepada petutur untuk mengirimkan CV (riwayat hidup)nya. Hal tersebut membuat petutur melakukan hal yang diminta oleh penutur, yaitu tindakan mengirim $\mathrm{CV}$.

Austin mengelompokkan tindak tutur menjadi tiga, pertama Tindak Lokusioner (locutioner $a c t$ ), adalah tindak yang semata-mata menyatakan sesuatu (hanya dengan kata-kata), biasanya dipandang kurang penting dalam kajian tindak tutur.Kedua, Tindak Ilokusioner (ilocutioner act) adalah apa yang ingin dicapai oleh penuturnya pada waktu menuturkan sesuatu dan tindak ini disebut juga dengan tindak melakukan sesuatu. Pada tindak ini seseorang berbicara mengenai maksud, fungsi, atau daya ujaran. Ketiga, Tindak Perlokusioner (perlocusioner act), yaitu tindakan untuk mempengaruhi lawan tutur, tindakan ini mengacu pada efek yang dihasilkan penutur dengan mengatakan sesuatu. Berdasarkan hal tersebut memuji merupakan tindak ilokusioner karena seseorang mengujarkan suatu pujian mempunyai maksud tertentu.

Sementara itu, Searle (dalam Leech, 1983:164-166) mengelompokkan ujaran dalam lima makro fungsi, yaitu.

\section{Komisif atau Koui Kousoku Gata（行為拘束型）}

Tindak tutur yang berisi komitmen dari penutur untuk melakukan sesuatu, seperti berjanji, bersumpah, bernazar, mengancam dan berikrar. Tindak tutur ini cenderung berfungsi menyenangkan dan kurang bersifat kompetitif, karena tidak mengacu pada kepentingan penutur tetapi pada kepentingan petutur. Berikut ini contoh tindak tutur berjanji.

(2) 私はあなたに電話することを約束します。

(Leech, 1993)

'Saya berjanji kepadamu untuk menelepon.'

Pada kalimat (2) ini, ungkapan 電話することを約束します‘berjanji untuk menelepon’ berisi komitmen penutur yang berjanji untuk menghubungi petutur melalui telepon. Setelah mengucapkan tuturan tersebut, petutur pun mengetahui bahwa penutur akan menghubunginya nanti.

\section{Direktif atau Koui Setsuji Gata（行為指示型）}

Tindak tutur ini bertujuan menghasilkan suatu efek berupa tindakan yang dilakukan petutur. Dengan kata lain, tindak tutur ini berisi bagaimana penutur mempengaruhi petutur. Tindak tutur ini termasuk dalam kategori kompetitif, karena membutuhkan kesantunan negatif. Seperti menyarankan, menganjurkan, menasehati, memohon, memerintah, menyuruh, amanat, dan wasiat. Namun, ada pula tindak tutur direktif yang memang sopan, seperti mengundang. Berikut ini contoh tindak tutur memerintah.

（3）田中：工場の中で機械や製品に触らないでください。

ラオ：わかりました。

Shin Nihongo no Kiso I (AOTS, 1990:137)

Tanaka : 'Jangan memegang mesin dan barang produksi didalam pabrik.'

Rao : ' 'Saya mengerti.'

Pada percakapan (3) ungkapan 触らないでください ‘jangan memegang' memaparkan secara langsung bahwa Tanaka memerintah Rao untuk tidak memegang mesin dan barang produksi. Setelah mengucapkan tuturan tersebut, Rao langsung mengerti maksud tuturan Tanaka, sehingga ia melakukan seperti apa yang diperintahkan oleh Tanaka. 


\section{Ekspresif atau Kanjou Hyougen Gata （感情表現型）}

Tindak tutur yang berfungsi mengungkapkan atau mengutarakan sikap psikologis penutur terhadap keadaan yang tersirat. Seperti memuji, meminta maaf, mengkritik, mengeluh, menyesal, mengucapkan selamat dan mengucapkan terima kasih. Tindak tutur ini cenderung menyenangkan, karena diungkapkan dengan kesantunan positif. Berikut ini contoh tindak tutur terima kasih.

(4) ラオ： 308 お願いします。

木村：はい、どうぞ。これはあなたの手紙ですか。

ラオ：はい、そうです。どうもありがとうございます。

Shin Nihongo no Kiso I (AOTS, 1990:137)

Rao : : 'Tolong 308.'

Kimura : 'Ya, silakan. Apakah ini surat untuk anda?'

Rao : ' 'Ya, benar. Terima kasih banyak.'

Pada contoh (4) ucapan Rao yaitu, どうもありがとうございます 'terima kasih banyak' diungkapkan untuk mengutarakan terima kasih karena Kimura telah memberikan surat untuk Rao.

\section{Deklaratif atau Sengen Gata（宣言型）}

Berhasilnya pelaksanaan tindak tutur ini mengakibatkan adanya kesesuaian antara isi proposisi dengan realitas atau dengan kata lain berfungsi menyatakan sesuatu dan mengubah status, seperti mengundurkan diri, menghukum, membaptis, menikahkan, menobatkan, melarang, memberi maaf, mengizinkan dan memutuskan. Tindak tutur ini merupakan suatu tindakan kelembagaan (dan bukan sebagai tindakan pribadi), sehingga tidak melibatkan faktor kesantunan. Berikut ini contoh tindak tutur melarang.

(5) ローラ：このしばふはきれいですね。しばふに入ってもいいですか。

小林 : ええ、入ってもいいです。でも、しばふの上で運動したりしてはいけません。

Shokyu Nihongo, (TUFS-JLC, 1990:116)

Rora : 'Halaman rumput ini bagus ya. Bolehkah masuk ke halaman rumput ini?'

Kobayashi : 'Ya, boleh masuk. Tetapi di atas halaman rumput ini tidak boleh berolahraga.'

Pada contoh (5) ini, tuturan yang diungkapkan Kobayashi yaitu, しばふの上で運動したりして はいけません'Di atas halaman rumput ini tidak boleh berolahraga' saat melarang Rora merupakan tindakan menyatakan sesuatu sesuai dengan aturan yang Kobayashi ketahui. Tuturan larangan tersebut dapat dilihat sebagai acuan dari suatu kelembagaan. Tuturan Kobayashi tidak disertai dengan faktor kesantunan karena jika disertai kesantunan maka akan mengecilkan daya deklarasi dari tuturan tersebut.

\section{Representatif atau Dangen Gata（断言型）}

Tindak tutur ini terikat pada kebenaran proposisi yang diungkapkan, sehingga dapat dibuktikan kebenarannya, seperti menyatakan, menuntut, mengakui, melaporkan, menunjukkan, menyebutkan, beragumentasi, memberikan kesaksian dan berspekulasi. Tindak tutur ini melibatkan kesantunan positif, kecuali membual dan mengeluh yang melibatkan kesantunan negatif. Berikut ini contoh tindak tutur menyebutkan.

(6) 日本の行事はたいてい中国から来ました。

Japanese for Today, (Yoshida, 1973:80)

'Acara perayaan Jepang sebagian besar datang dari Cina.'

Tuturan (6) tersebut yaitu 中国から来ました 'datang dari Cina' menyatakan kebenaran bahwa acara perayaan di Jepang berasal dari Cina. Tuturan tersebut dapat dibuktikan kebenarannya melalui data-data sejarah yang akurat. 
Berdasarkan penjelasan teori di atas, penulis menyimpulkan hubungan antara tindak ilokusioner, tindak tutur ekspresif serta kaitannya dengan kesantunan positif sebagai berikut. Tindak ilokusioner seperti yang telah dijelaskan di atas berbicara mengenai maksud, fungsi, atau daya ujaran dengan kata lain untuk apa seseorang mengujarkan sesuatu tersebut. Tindak tutur memuji termasuk ke dalam ekspresif, menunjukkan maksud penutur saat mengungkapkan atau mengutarakan pujian tersebut. Maksud pujian yang diungkapkan penutur adalah untuk menyampaikan penilaian positif terhadap petutur.

\section{Jenis Tindak Tutur Memuji}

Jenis memuji pada penelitian ini akan menggabungkan pendapat Holmes dan Mizutani dan Mizutani untuk saling melengkapi. Holmes (2003:187) mengelompokkan jenis-jenis pujian menjadi empat, yaitu pujian terhadap penampilan petutur (appearance compliment), pujian terhadap kemampuan, prestasi atau perbuatan baik petutur (ability/performance compliment), pujian terhadap benda yang dimiliki petutur (possesions compliment), pujian terhadap terhadap kepribadian atau keramahan petutur (personality/friendliness), dan pujian terhadap kepribadian atau keramahan petutur (personality/friendliness).

Sementara itu, Mizutani dan Mizutani (1987:149-152) membagi jenis pujian menjadi lima jenis. Tiga jenis di antaranya sama seperti yang diungkapkan oleh Holmes, yaitu pujian terhadap benda milik orang lain, pujian terhadap pakaian atau penampilan seseorang serta pujian terhadap kemampuan seseorang, sedangkan dua jenis tidak diungkapkan oleh Holmes, yaitu pujian terhadap tempat tinggal seseorang dan pujian terhadap keluarga seseorang.

\section{Pujian terhadap Penampilan Petutur (appearance compliment)}

Pujian diungkapkan ketika penutur mengagumi penampilan petutur. Pujian ini mengacu pada apa yang dikenakan oleh petutur. Orang Jepang tidak terbiasa mengungkapkan pujian terhadap penampilan seseorang, kecuali jika penutur dan petutur memiliki hubungan yang akrab.

\section{Pujian terhadap Kemampuan, Prestasi atau Perbuatan Baik Petutur (ability/ performance compliment)}

Pujian diungkapkan ketika penutur mengagumi kemampuan yang diperlihatkan petutur, prestasi yang dihasilkan petutur ataupun perbuatan baik yang dilakukan petutur (misalnya, untuk menolong orang lain dan sebagainya). Pujian ini mengacu pada apa yang dilakukan oleh petutur. Tidak biasa bagi orang Jepang memuji kemampuan seseorang, kecuali di antara teman akrab atau diungkapkan kepada seseorang yang lebih muda.

\section{Pujian terhadap Benda yang Dimiliki Petutur (possesions compliment)}

Pujian diungkapkan ketika penutur mengagumi sesuatu yang dimiliki petutur karena bentuknya yang bagus. Pujian ini mengacu pada benda yang dimiliki petutur. Pujian ini dianggap sebagai hal yang tidak biasa; di dalam situasi yang sopan seseorang akan berhenti memuji benda orang lain secara langsung. Bagaimanapun, pujian seperti itu akan berubah di antara orang yang lebih akrab satu sama lain.

\section{Pujian terhadap Kepribadian atau Keramahan Petutur (personality/ friendliness)}

Pujian diungkapkan ketika penutur mengagumi kepribadian petutur atau sikap petutur yang ramah. Pujian ini mengacu pada kepribadian petutur. 


\section{Pujian terhadap Tempat Tinggal Seseorang}

Pujian terhadap tempat tinggal seseorang adalah biasa, bahkan di dalam situasi yang sopan. Jika seseorang memuji orang lain maka orang lain yang dipuji tersebut akan menyangkal dengan mengatakan poin kelemahan dari tempat tinggalnya.

\section{Pujian terhadap Keluarga Seseorang}

Memuji anggota keluarga orang lain seperti anak orang lain adalah sangat biasa; semakin muda usia anak mereka, maka semakin mudah untuk memujinya. Seseorang tidak bebas memuji anggota keluarga yang telah dewasa. Faktor keanggotaan kelompok mempengaruhi pengungkapan jenis pujian ini. Penutur yang berada di lingkungan luar keluarga (soto) menyebabkan rasa sungkan memuji anggota keluarga petutur yang berada di lingkungan dalam (uchi). Oleh karena itu, pujian ini dituturkan kepada anggota keluarga petutur, bukan langsung kepada petutur. Pada jenis pujian ini, penutur menyampaikan pujiannya mengacu pada penampilan fisik, kemampuan serta kepribadian keluarga petutur.

\section{Muka, Kesantunan, dan Strategi}

Menurut Yule (2006:104), kesantuna dalam suatu interaksi dapat didefinisikan sebagai alat yang digunakan untuk menunjukkan kesadaran tentang wajah seseorang, sedangkan wajah itu sendiri, menurut Brown dan Levinson merupakan dasar teori kesantunan. Wajah (yang selanjutnya akan disebut muka) merupakan wujud pribadi seseorang dalam masyarakat (Yule, 2006:104).

Muka mengacu kepada makna sosial dan emosional itu sendiri yang setiap orang memiliki dan mengharapkan orang lain untuk mengetahui. Dengan demikian pengertian mengenai muka adalah sesuatu yang emosional, dicurahkan dan dapat hilang, dipertahankan atau ditingkatkan dan harus diperhatikan secara konstan di dalam interaksi.

Muka merupakan sesuatu yang berhubungan dengan citra diri atau image seseorang. Tindak tutur memuji berkaitan dengan tindak tutur menyelamatkan muka (Face Saving Act/FSA). Dalam tindak tutur memuji, penutur menghasilkan muka positif. Brown dan Levinson (1987:61) mengungkapkan bahwa muka positif mengacu pada citra diri setiap orang yang berkeinginan agar apa yang dilakukannya, apa yang dimilikinya atau apa yang merupakan nilai-nilai yang ia yakini diakui orang lain sebagai suatu hal yang baik, yang menyenangkan, yang patut dihargai. Muka positif melahirkan kesantunan positif.

Adapun muka negatif seseorang ialah kebutuhan untuk merdeka, memiliki kebebasan bertindak, dan tidak tertekan orang lain. Selanjutnya jika penutur melakukan tindak tutur mengancam muka (Face Threating Act/FTA) pada muka negatif untuk menunjukkan rasa hormat, menekankan pentingnya minat dan waktu orang lain, dan bahkan termasuk permintaan maaf atas pemaksaan atau penyesalan maka akan menghasilkan kesantunan yang negatif bagi petutur (Yule, 2006:107).

Strategi menurut Brown dan Levinson terdiri atas:

- Bertutur terus terang tanpa basa-basi (bald on record). Yaitu suatu tuturan, misalnya suatu permintaan yang ditujukan secara langsung kepada orang lain dimana tekanan ilokusinya dibuat eksplisit)

- Berterus terang dengan basa-basi yang berupa kesantunan positif (on record with positive politeness. Pada hakekatnya kesantunan positif ditujukan terhadap muka positif petutur

- Berterus terang dengan basa-basi yang berupa kesantunan negatif (on record with negative politeness. Kesantunan negatif pada hakikatnya ditujukan terhadap bagaimana memenuhi dan 
atau menyelamatkan sebagian muka negatif petutur, yaitu keinginan dasar petutur untuk mempertahankan apa yang dia anggap sebagai wilayah dan keyakinan dirinya.

- Bertutur secara tidak terus terang atau samar-samar (off record). Petutur membuat suatu tuturan dengan ungkapan lain, sehingga petutur dibiarkan menginterpretasikan sendiri apa yang diujarkan oleh penutur.

- Bertutur didalam hati (diam) (Don't the FTA). Penutur tidak menuturkan apapun kepada lawan tutur (petutur) melainkan bertutur di dalam hati saja.

\section{Analisis Tindak Tutur Memuji}

\section{Jenis Pujian terhadap Penampilan Petutur}

\section{Data 1}

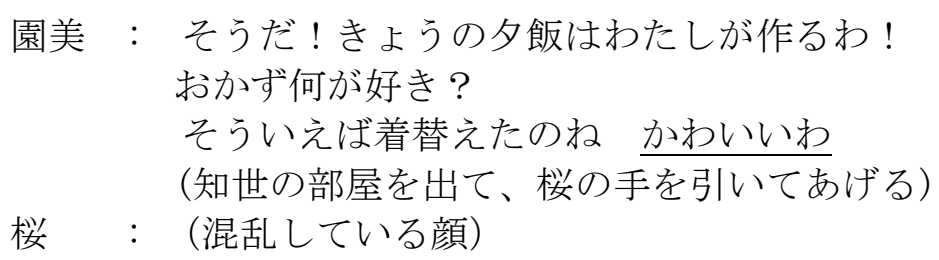

Sonomi: 'Ah ya! Makan malam hari ini biar tante yang masak.

Kamu suka apa? Oiya kamu ganti baju ya cantiknya'

(keluar kamar Tomoyo sambil menarik tangan Sakura)

Sakura : (dengan raut muka yang terlihat bingung...)

Percakapan pada data 1 terjadi di dalam kamar Tomoyo antara ibu Tomoyo yang bernama Sonomi dengan Sakura. Pada saat itu Sakura sedang mengunjungi rumah sahabatnya Tomoyo dan berada di dalam kamar Tomoyo untuk membantu membuka kotak milik Tomoyo dan ibunya. Kemudian tiba-tiba Sonomi masuk ke dalam kamar dan menarik Sakura keluar untuk menyiapkan makanan. Sonomi pun memuji penampilan Sakura yang telah mengganti pakaiannya. Pada saat Sonomi tiba di rumah Sakura, Sakura masih menggunakan baju yang sangat sederhana.

Pada data 1, ungkapan かわいいわ 'cantiknya' memperlihatkan bahwa Sonomi memuji penampilan Sakura yang berubah menjadi cantik dan manis setelah mengganti pakaiannya. Pujian Sonomi tersebut termasuk ke dalam pujian terhadap penampilan seseorang karena topik pujian Sonomi mengacu pada penampilan Sakura setelah dia mengenakan pakaian lain. Pada data 1, alasan Sonomi memuji Sakura adalah untuk mengekspresikan rasa kagum terhadap penampilan Sakura yang berubah setelah mengganti pakaiannya dan atas kemiripan rupa wajah Sakura dengan ibunya, yaitu Nadeshiko yang sangat disayangi Sonomi.

Strategi yang dilakukan penutur saat mengutarakan pujiannya adalah strategi bertutur terus terang dengan kesantunan positif. Strategi tersebut ditunjukkan ketika Sonomi menyatakan secara langsung penghargaannya terhadap penampilan Sakura yang berubah menjadi cantik setelah mengganti bajunya. Sementara respon Sakura saat dipuji, ia menganggap pujian adalah sesuatu yang positif karena menyelamatkan mukanya dari ketidaktepatan penampilannya pada saat itu.

\section{Jenis Pujian terhadap Kemampuan, Prestasi, atau Perbuatan Baik Petutur}

Data 2

$$
\begin{array}{ll}
\text { 奈緒子 : } & \text { 山崎君上手ね- } \\
\text { 千春 } & \text { けっこう器用だから }
\end{array}
$$


Naoko : 'Yamazaki pintar ya'

Chiharu : 'Karena dia memang punya bakat'

Pada data 2, percakapan antara Naoko dan Chiharu terjadi di dalam kelas musik saat mereka sedang mengikuti tes bermain seruling. Ketika melihat permainan seruling Yamazaki yang bagus, Naoko pun memuji permainan seruling pemuda itu. Kemudian Chiharu pun menyetujui pujian Naoko dengan mengakui bakat Yamazaki. Yamazaki Takashi adalah murid kelas dua di Sekolah Dasar Tomoeda serta teman laki-laki yang sekelas dengan Naoko dan Chiharu. Naoko Yanagizawa dan Chiharu Mihara adalah murid kelas dua di Sekolah Dasar Tomoeda.

Pujian dalam data 2 ditunjukkan dengan penggunaan kata jouzu 'pintar' pada kalimat 山崎君 上手放—— 'Yamazaki pintar ya' yang dituturkan Naoko menjelaskan bahwa Naoko memuji kemampuan Yamazaki dalam bermain seruling. Oleh karena topik pujian Naoko mengacu pada kemampuan Yamazaki yang pintar bermain seruling, sehingga pujian Naoko tersebut termasuk ke dalam pujian terhadap kemampuan seseorang.

Pada data 4, alasan Naoko dan Chiharu memuji Yamazaki adalah untuk menggambarkan penilaian positif akan kemampuan Yamazaki dapat bermain seruling dengan sangat bagus. Strategi yang dilakukan penutur saat mengutarakan pujiannya adalah strategi bertutur terus terang dengan kesantunan positif. Strategi tersebut dapat ditunjukkan dengan penghargaan Naoko kepada Yamazaki dengan cara memperhatikan dan mengikuti kemampuan Yamazaki yang pintar bermain seruling.

\section{Jenis Pujian terhadap Benda yang Dimiliki Petutur}

Data 3

$$
\begin{array}{lll}
\text { 桜 } & \text { きれいなブーケですね } \\
\text { 園美 : } & \text { これはね あなたのおけさん 撫子の結婚式のときのブーケよ }
\end{array}
$$

Cardcaptor Sakura 3 (Clamp, 2001:113)

Sakura : 'Buket yang cantik ya'

Sonomi: 'Ini ya milik ibumu. Buket Nadeshiko waktu acara pernikahannya'

Pada data 3, percakapan antara Sonomi dan Sakura terjadi di dalam kamar Tomoyo antara ibu Tomoyo yang bernama Sonomi dengan Sakura. Setelah Sakura berhasil membuka kotak penyimpanan benda berharga milik Tomoyo dan ibunya, yaitu Sonomi, Sakura melihat sebuah buket bunga cantik yang terletak di dalam kotak tersebut. Sakura pun memuji buket bunga tersebut. Pujian pada data 3 ditunjukkan dengan penggunaan kata kirei 'cantik' pada tuturan Sakura, yaitu pada ungkapan きれい なブーケですね ‘Buket yang cantik ya'. Pujian tersebut memaparkan bahwa Sakura memuji betapa cantiknya benda yang dimiliki Sonomi, yaitu sebuah buket bunga. Oleh karena itu, pujian Sakura tersebut termasuk ke dalam pujian terhadap benda yang dimiliki seseorang.

Pujian yang dituturkan oleh wanita biasanya berfungsi untuk mengungkapkan bentuk kekaguman atas suatu hal yang positif. Demikian juga dengan pujian Sakura, alasan Sakura memuji Sonomi adalah untuk mengekspresikan kekagumannya terhadap benda yang dimiliki Sonomi, yaitu buket bunga yang cantik.

Strategi yang dilakukan penutur saat mengutarakan pujiannya adalah strategi bertutur terus terang dengan kesantunan positif. Strategi tersebut dapat ditunjukkan dengan penghargaan Sakura kepada Sonomi dengan cara memperhatikan dan mengikuti benda yang dimiliki Sonomi, yaitu buket bunga yang cantik. Sementara respon Sonomi yang tersenyum saat dipuji berarti ia menganggap pujian adalah sesuatu yang positif karena menyelamatkan mukanya. 


\title{
Jenis Pujian terhadap Kepribadian atau Keramahan Petutur
}

\author{
Data 4

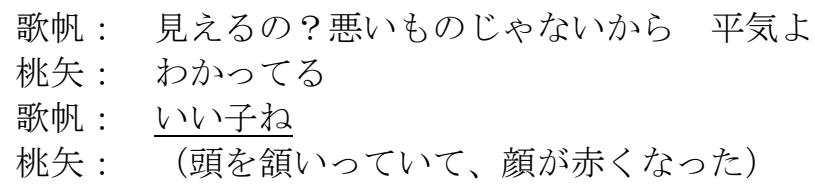

Kaho : 'Kamu bisa melihatnya ya? Itu bukan sesuatu yang buruk kok, jadi kamu tidak usah bingung

Touya : 'Aku tahu'

Kaho : 'Anak baik'

Touya : (menundukkan kepala, kemudian mukanya memerah)

Pada data 4, percakapan antara Kaho dan Touya terjadi di depan Kuil Tsukimine, ketika Touya sadar dapat melihat 'sesuatu' pada sebuah pohon. Kahoo mengatakan bahwa 'itu' bukanlah sesuatu yang buruk. Touya pun menjawab bahwa ia sudah mengetahui bahwa 'itu' bukan sesuatu yang buruk dan Touya tidak akan mengganggu 'sesuatu' pada pohon tersebut. Oleh karena kebaikan Touya tersebut, maka Kaho memuji kepribadian Touya.

Pujian pada data 4 ditunjukkan dengan ungkapan いい子ね ‘Anak baik' yang dituturkan oleh Kaho yang memuji kepribadian Touya yang baik karena tidak berniat mengganggu 'sesuatu' yang terdapat pada pohon tersebut. Oleh karena itu, pujian Kaho termasuk ke dalam pujian terhadap kepribadian seseorang.

Wanita terbiasa untuk memuji orang lain sebagai bentuk kekagumannya. Sementara laki-laki menganggap pujian adalah sesuatu yang negatif dan bahkan berpotensi mengancam muka. Alasan pujian yang dituturkan oleh Kaho adalah untuk mengekspresikan kekagumannya terhadap kemampuan Touya. Akan tetapi, Touya bersikap seolah-olah tidak menerima pujian Kaho dengan diam tanpa mengatakan sepatah katapun dan merasa sangat malu.

Strategi yang dilakukan penutur saat mengutarakan pujiannya adalah strategi bertutur terus terang dengan kesantunan positif. Strategi tersebut dapat ditunjukkan dengan penghargaan Mizuki Kaho kepada Touya dengan cara memperhatikan dan mengikuti kepribadian Touya yang baik karena tidak berniat mengganggu 'sesuatu' yang terdapat pada pohon tersebut. Akan tetapi, respon Touya malah menganggap pujian Mizuki Kaho tersebut merupakan sesuatu yang negatif, sehingga berpotensi mengancam mukanya.

\section{Jenis Pujian terhadap Tempat Tinggal Seseorang}

\section{Data 5}

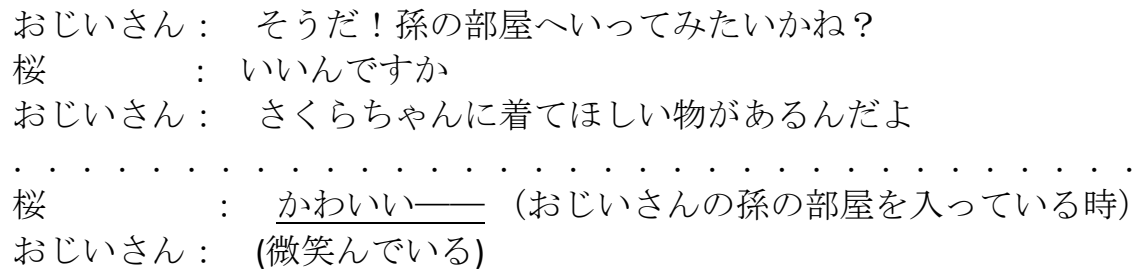

Kakek : 'Oh iya! Mau lihat kamar cucu?'

Sakura : 'Bolehkah?'

Kakek : 'Ada yang ingin kakek minta Sakura pakai' 
Sakura : 'Indahnya...' (sewaktu masuk ke dalam kamar cucu kakek)

Kakek : (tersenyum)

Pada data 5, percakapan antara kakek dan Sakura terjadi di dalam perjalan dari teras rumah kakek ke dalam kamar cucu kakek, ketika Sakura berkunjung ke rumah kakek. Kakek adalah kakek yang baru ditemui Sakura saat Sakura berlibur dengan keluarganya. Kakek itu merupakan pemilik dari rumah mewah yang terletak di dekat penginapan Sakura dan keluarganya. Sebenarnya kakek tersebut adalah kakek dari Nadeshiko Amamiya, yaitu ibu Sakura. Akan tetapi, Sakura tidak mengetahuinya. Oleh karena itu, kamar yang ditunjukkan Sakura adalah kamar Nadeshiko, yaitu ibu Sakura. Sakura Kinomoto adalah anak kedua dari Fujitaka Kinomoto dan Nadeshiko Amamiya serta cicit dari kakek. Setelah Sakura diperlihatkan kamar cucu kakek itu, kemudian Sakura mengungkapkan pujiannya pada keadaan kamar tersebut.

Pujian pada data 5 ditunjukkan dengan ungkapan かわいい—— 'Indahnya...'yang dituturkan oleh Sakura. Pujian Sakura mengacu pada keindahan kamar cucu kakek tersebut. Oleh karena itu, pujian Sakura tersebut termasuk ke dalam pujian terhadap tempat tinggal seseorang. Pujian dituturkan wanita sebagai alat untuk mengekspresikan kekaguman. Demikian juga dengan Sakura, ia ingin menyampaikan rasa kagumnya sebagai bentuk penilaian positif terhadap tempat tinggal, yaitu sebuah kamar milik cucu kakek itu. Strategi yang dilakukan penutur saat mengutarakan pujiannya adalah strategi bertutur terus terang dengan kesantunan positif. Strategi tersebut dapat ditunjukkan dengan penghargaan Sakura kepada kakek dengan cara memperhatikan dan mengikuti keindahan kamar cucu kakek itu.

\section{Jenis Pujian terhadap Keluarga Seseorang}

Data 6

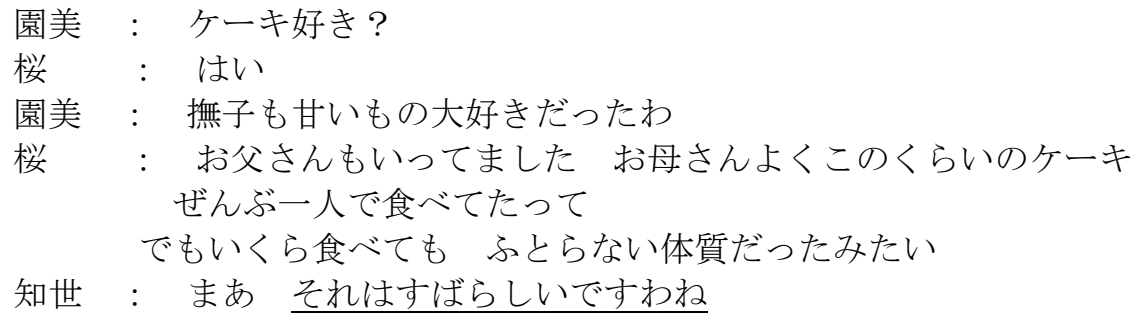

Sonomi : 'Kamu suka kue?'

Cardcaptor Sakura 3 (Clamp, 2001:104)

Sakura : 'Iya'

Sonomi : 'Nadeshiko juga suka sekali yang manis-manis'

Sakura : 'Ayah juga bilang, katanya ibu suka makan kue sebesar ini sendiri. Tapi walaupun makan banyak, dia tidak gemuk.'

Tomoyo: 'Wah... luar biasa ya'

Pada data 6, percakapan antara Sonomi dan Sakura terjadi di teras belakang rumah Sonomi, saat Sonomi tengah bercakap-cakap dengan Sakura sambil minum teh bersama. Pada saat itu Sakura sedang mengunjungi rumah sahabatnya Tomoyo, dan bercakap-cakap dengan Sonomi mengenai Nadeshiko, yaitu ibu Sakura. Oleh karena Nadeshiko tidak gemuk, walaupun kesukaannya makan makanan manis, lalu Tomoyo mengungkapkan pujiannya kepada Nadeshiko, yaitu ibu Sakura.

Pujian pada data 6 ditunjukkan dengan ungkapan それはすばらしいですわね 'wah luar biasa ya' yang dituturkan oleh Tomoyo. Pujian Tomoyo ditujukan kepada ibu Sakura, yaitu Nadeshiko yang tidak dapat gemuk walaupun menyukai makanan manis. Oleh karena itu, pujian Tomoyo tersebut termasuk ke dalam pujian terhadap anggota keluarga seseorang. Pujian Tomoyo ini mengacu pada penampilan fisik dari ibu Sakura yang bernama Nadeshiko Amamiya. 
Pujian dituturkan wanita sebagai alat untuk mengekspresikan kekaguman. Demikian juga dengan Tomoyo, ia ingin menyampaikan rasa kagumnya sebagai bentuk penilaian positif terhadap anggota keluarga Sakura, yaitu ibu Sakura yang bernama Nadeshiko. Strategi yang dilakukan penutur saat mengutarakan pujiannya adalah strategi bertutur terus terang dengan kesantunan positif. Strategi tersebut dapat ditunjukkan dengan penghargaan Tomoyo kepada ibu Sakura yang bernama Nadeshiko Amamiya dengan cara memperhatikan dan mengikuti penampilan ibu Sakura yang tidak dapat gemuk walaupun menyukai makanan manis.

\section{SIMPULAN}

Pujian merupakan salah satu alat yang diberikan penutur jika ingin mengungkapkan penilaian positif akan sesuatu yang ada pada diri petutur berdasarkan berbagai topik acuan. Topik pujian tersebut mengacu pada penampilan; kemampuan, prestasi, dan perbuatan baik petutur; benda yang dimiliki; kepribadian dan keramahan petutur; tempat tinggal seseorang serta anggota keluarga seseorang. Berdasarkan hasil analisis data ternyata wanita Jepang menggunakan berbagai bentuk memuji. Pujian yang dilakukan oleh wanita Jepang ditemukan pada semua jenis pujian, yaitu pujian terhadap penampilan petutur, pujian terhadap kemampuan, prestasi, tau perbuatan baik petutur, pujian terhadap benda yang dimiliki petutur, pujian terhadap kepribadian dan keramahan petutur, pujian terhadap tempat tinggal seseorang, dan pujian terhadap keluarga seseorang. Bentuk tindak tutur memuji yang digunakan かわいい、上手、きれいな、いい、すばらしい. Ditemukan kesamaan bentuk memuji pada pujian terhadap penampilan petutur dan terhadap tempat tinggal, yaitu menggunakan kata かわいい dan semua kata tersebut termasuk ke dalam adjektiva. Alasan penutur melakukan pujian, yaitu untuk mengekspresikan penilaian positif terhadap sesuatu yang dimiliki orang lain. Sementara itu, strategi yang digunakan oleh wanita saat mengungkapkan pujian adalah strategi berterus terang dengan kesantunan positif. Hal tiu sesuai dengan yang dikatakan Holmes bahwa memuji merupakan ungkapan dengan kesantunan positif.

\section{DAFTAR PUSTAKA}

AOTS (1995) Shin Nihongo no Kiso I. Japan: 3A Corporation.

Brown, P.,\& Levinson,S. (1987). Politeness: Some Universals In Language Use. Cambridge: Cambridge University Press.

CLAMP (2001).Cardcaptor Sakura. Tokyo: Kodansha.

Holmes, J. (2003). ‘Complimenting: A Positive Politeness Strategy'. Sociolinguistic: The Essential Readings.Oxford: Blackwell Publishers, pp.177-197.

Leech, G. (1993).Goyouron. (terj.) Yoshihito Ikegami. Tokyo: Kinokuniya Book Store.

Levinson, S. (1983). Pragmatics. London: Cambridge University Press.

Mizutani, O., \& Mizutani, N. (1987). How to be Polite in Japanese. Tokyo: The Japan Times.

Nadar, F.X. (2009). Pragmatik dan Penelitian Pragmatik. Yogyakarta: Graha Ilmu.

Sunagawa, Y. (1998) Nihongo Bunkei Jiten. Tokyo: Kuroshio 
Tokyo University of Foreign Studies, Japanese Language Center (1990). Shokyu Nihongo. Tokyo: Bonjinsha.

Yule, G. (2006). Pragmatik. (terj.) Indah Fajar Wahyuni dan Rombe Mustajab. Yogyakarta: Pustaka Pelajar.

Yoshida, Y. (1973). Japanese for Today, Tokyo: Gakken. 